\title{
PROBLEMS OF ECONOMIC SECURITY IN RUSSIAN TRANSPORTATION AND INTERMEDIATE CARRIER INFRASTRUCTURE
}

This paper reviews the basic problems of economic security in infrastructural ensuring of the implementation of transportation and intermediate carrier potential of Russia: development and reconstruction of communication lines, usage of innovative transportation methods, building a network of transportation and logistics centers, development of regional airport hubs and others. Particular attention is paid to the problems of transportation and transit potential implementation of Siberia and the Far East. It is shown that the increase of transit facilities in the territory of Russia takes place in a competitive market of infrastructure projects. At the same time it is emphasized that along with exhausting the possibilities of commodity economy development, a natural competitive advantage of Russia as a transport bridge between Europe, Asia and America will be implemented in full force.

Keywords: economic security, transportation and transit potential, intermediate carrier potential, infrastructure projects funding, modernization of the economy, public-private partnership

Territorial development of the Russian economy is running in terms of a competition between the regions for the sources of budget revenues, investments and human resources. Development of transport infrastructure results in improved quality of life, attractiveness of the area for the population and investors. Implementation of transit freight and passenger transfer creates focal points of sustainable economic activity, new positions of employment; it is driving the growth of tax and nontax revenues of regional budgets. All these parts are constituent elements of Russia's economic security $[1,4,5]$.

The need to improve and implement transportation and transit facilities in the regions in order to increase the economic security of the country is due to the fact that, to date, there is no tendency to increase the degree of raw materials processing and the creation of high-tech companies is insufficient and little enclaves-alike. As the financial crisis is being mastered, the import amounts of consumer goods, machinery and equipment increase. Industrial development has gone through the organization of assembly plants, which functioning also needs improvement of the transport infrastructure. However, transportation companies are being incorporated into the production process of assembly plants in terms of outsourcing, supplying components and materials just in time. For example, this technology is used by JSC «Transcontainer», a subsidiary of JSC «RZD Russian Railways», in the supply of car kits to the Volkswagen plant in Kaluga. The railway operator intends to offer all automotive factories a 
number of automotive transportation services for container trains.

Economic activity is concentrated in Moscow, Saint Petersburg and regions of commodities. According to the pace of economic growth and the value of investments attracted, the authors distinguish: largest urban agglomerations, commodity exporting and coastal regions, territories located in the profitable trade routes.

The implementation of transportation and intermediate carrier potential of Russia allows launching the process of organic raw material economy transformation into the economy of innovational type, including the export of high-tech transportation services.

Development of the Russian intermediate carrier is an investment in the infrastructure of the regions and the creation of these positions of employment, strengthening the cohesion of the Russian economic space. Most of the subjects of the Russian Federation believe that they have a favorable geographical position and are located at the intersection of the main routes from Europe to Asia.

However, while large-scale implementation of infrastructure projects is taking place on the main directions of export flow primarily through the development, modernization and privatization of ports. Increased demand for raw materials (mainly coal and oil) in the Asia-Pacific region has led to formation of high-power port hubs in the Far Eastern region - Eastern and Vanino-Sovgavanskiy.

The implementation of transport projects is based on developments, plans and design estimates sketched back in the days of the USSR times, consolidating and extending the existing economic development already oriented on raw materials. However it is notable that the logistics of the deficit economy is easier and more efficient from a technological point of view rather than the process of commodity circulation in the market economy with limited purchasing power. Storage capacities built in the Soviet Union provided storage of large volumes of industrial goods while market economy is dominated by the mass flow of consumer demand goods. Therefore, improvement of goods transportation system demands that logistics centers provide treatment of small retail volumes of trade flows.

\section{Main threats to the Russian transport infrastructure security}

A threat to the Russian transport infrastructure security is the presence of the barrier places on the railway network, for example, areas with limited traction power supply, which increases the range of motion of heavy compounds in the same direction. A barrier place to the movement of cargo to the East is the low capacity of the railway infrastructure, as well as shortcomings in the organization of the operational work of the Eastern Road landfill (inefficient use of locomotives and locomotive crews plus capacity of existing stations and spans). Ensuring economic security requires the involvement of ports and export companies in financing the development of railway infrastructure.

Improvement of transport infrastructure safety facilitates separation of existing rail freight by type and construction of specialized lines for transportation of bulk cargo, transportation of passengers, containers and lightweight freight. Transportation on freight lines will increase the weight of the train units and reduce the requirements for the content of the railway infrastructure. The usage of specialized lines can speed up the transportation and provide «fixed» schedule of trains plying.

Countermeasures to monopolization tendencies in the ports. The volume of cargo handling in ports is already one third higher than the maximum rates of the former Soviet Union. The ports cannot cope with the export of raw materials and do not provide timely processing of import and export flows. The cost of cargo handling is comparable to the cost of their transportation. Corrective actions will help to increase competition between ports, transportation and logistics centers located at land border crossings and inland areas.

Transportation and logistics centers can act as specialized and universal rear terminals, including customs, to serve the needs of the maritime cargo area. They should be connected between themselves and with the sea ports within a united technological process. This is especially true where the opportunities for the development of railway infrastructure are limited due to urban real estate development, such as Vladivostok transport node. The way to solve this situation might be the transfer of the main part of the marshalling and shunting operations to form the Vladivostok transportation hub, while marine shipments will be made at the port in a unified technological processing schedule for the exact arrival time of a particular ship. JSC «RZD - Russian Railways» plans to develop the concept of transportation and logistics centers «Primorskiy» (in the Maritime Territory / PrimorskiKrai), «Baltijskiy» (Saint Petersburg) and «Tamanskiy» (Krasnodar Krai). 
Creation of rear terminals («dry ports») which are able to provide the full range of services for cargo (accumulation of ship parties, reception, storage, processing and their subsequent motion), will promote uniformity of regional development. Growth and efficiency of cargo handling in seaports promotes the development of inland regions. So, with the creation of the Far Eastern Transport Corridor for transshipment of grain through the commercial sea port of Vladivostok (in the amount of 1.5 million tons per year), heavy loading regions in the first place will be Omsk, Novosibirsk, Amur regions and Altai Krai, as well as the exporters of grain from Kazakhstan. The effectiveness of this grain crops corridor depends, first of all, on the level of tariffs for railway transportation.

In the case where a private company is developing a terminal, the goods of this company are having benefits; one company may own both access and railway tracks. To overcome the problems associated with the conflict of interests of owners in the organization of intermodal transport, transportation facilities should be controlled by the management company, especially those located in the port and on the approaches to it (roads, rail sidings and stations). Federal involvement should be, above all, in financing the dredging works.

\section{Development of container traffic and the problems of Russia's economic security}

Transit features of the main traffic artery of the country - Trans-Siberian Railway - are not used at full force: from January to October 2010, only 26.7 thousand transit containers (TEUs) were carried, although the increase in traffic to 2009 was $83 \%$.

Trans-Siberian route of the intermodal transit comprises marine areas connecting the Far East Russian ports to the ports of China, Japan, South Korea and others. The cost of transit tariff policy is affected by shipping companies, ports, stevedoring companies and freight forwarders. The components of the tariff are subject to reciprocal compensation: the reduction of tariff rates of JSC «RZD» is offset by the rate growth of shipping, stevedoring and forwarding companies. The level of pass-through rate is determined under the influence of carrier transport tariffs in Belarus, the Ukraine and Europe. By the large means, Trans-Siberian way is used by shippers from Far East and Asia-Pacific Region countries as a pressure argument to sign lucrative contracts with transoceanic carriers.
According to the Transport Strategy of Russia until 2030, over the next 20 years just the transit flows in the country should increase from 28 to 100 million tons. Perspective income only from transit traffic by railway network may be up to 10 billion US dollars a year.

The innovative technology of container transportation in Russia has not received proper distribution. In developed countries, the level of container traffic reaches $40-60 \%$ of the total volume of freight traffic. In Russia, the level of containerization does not exceed $6-10 \%$, and in rail transport does not exceed $1.6 \%$. The level of containerization on the railroads in the U.S. is about $6.4 \%$, on Chinese railways about $2.4 \%$.

There are many small operators in the Russian market of container transportation who are unable to work effectively in the Eurasian transport market. Formation process of complete container trains is available only to large transport operators on the most popular areas. The composition of a container train includes 57 and 71 conventional coaches (platform). At the same time, the recognition of a train consisting of 57 conventional coaches as a complete one requires permission of the Central Direction of Motion at JSC «RZD». Unbalanced economic structure and external trade lead to an increase in the proportion of empty containers run. Currently, over $50 \%$ of the containers from Russia to Europe and not less than $40 \%$ from Russia to Asia are running empty; a process of joining of flows coming from the opposite direction is not realized. Providing such a joining process requires a centralized operating of a large number of containers [3].

It is necessary to revive the system of transit goods transportation on the basis of contracts with a consolidated state-owned operator of the country for multimodal and intermodal transit operations by operators - foreign trade cargo forwarders in Europe and Asia. The stablishment of a national container operator JSC «Rostranzit» by analogy with existing at the time of the former Soviet Union Foreign Trade Association «Soyuztransit» is required. A pool of Russian container owners in order to reduce the cost of storing and transporting empty containers might be created. For example, in Western Europe, dozens of pools of containers and pallets exchange services are involved [2].

At the end of 2010, documents to establish a joint Russian-Chinese venture for container transportation by railways have been signed. The founders of the joint ventures have become «Transcontainer» 
(«daughter» of «Russian Railways») and the China Railway Company on international multimodal transport (CRCT). The new company plans to increase the share of total shipments of containerized cargo by railways between China and Russia from $12.5 \%$ in 2010 up to $40 \%$ by 2015 , the joint venture will provide transportation and logistics services on the routes that pass through the border crossings of Manchuria-Zabaikalsk and Alashankou-Dostyk. A positive role is also played by the establishment of the Russian-German-Chinese joint venture for the transit of containers.

There is a need for a network of container logistics centers in the arrangement of the Russian railway network in the major hub of regional centers, where interaction between different modes of transport is going on. Transit development requires organization of interterminal connection, a combination of the largest container terminals in sea transport nodes with less powerful logistics facilities in the country. Improving the competitiveness and efficiency of the terminal can be achieved by the means of their connections into a consolidated network with the launch of regular container trains on a solid schedule, and automobile connection.

Lack of proper logistics terminals can be compensated by the extension of routes to other countries - participants of the transit chain. A construction project of the railway to South Korea and the extension of the gauge width of $1520 \mathrm{~mm}$ up to Vienna, where the largest transportation and logistics hub in Europe is located, are worth mentioning. Implementation of works to extend the Russian railway gauge from Kosice to Bratislava and Vienna will increase the transit cargo from Russia to Europe by $60 \%$.

The port of Klaipeda (Lithuania) has been chosen for the transit of goods to Afghanistanof the United States and the countries - members of the NATO. It was decided to include the port into the Northern Distribution Network. Cargo through the port of Klaipeda is already being delivered by Germany and the UK.

To the enhancement of container transport security also contributes the modernization of rolling stock, for example, the use of generic platforms with interchangeable set of fittings that would effectively carry out the loading and transportation of various types of containers, including non-standard tank-containers. To ensure the stability, the rail container operators in addition to container platforms should have a system of economic activity provision: terminals, ports, containers, and even their own ships.

To improve the safety of the transport containers by rail, they are put onto the platform by two with the doors inside to obstruct unauthorized penetration. However, the competitive advantages of the passage in 2010 of complete trains on the route Hamina - Buslovskaya - Nakhodka East were secured by allowing the loading of containers on the platform with the doors to the outside in order to reduce the time of customs clearance.

\section{Problems of economic security in the formation of a network of transport and logistics centers}

High costs of export-import operations are due to the remoteness of the majority of Russian regions from the external borders and cheap transport communications. The increase in traffic (including transit) will reduce the proportion of fixed costs in the cost of transport services. Construction of railways in the Far North is a means of reducing the cost of consumer goods.

The development of the transit network and the formation of TLC network will help solve the problem of connectedness of large cities - regional centers, because now transport links between them are now often carried out through Moscow. Creation of transport and logistics centers (TLC) in the Russian regions is done to attract import and transit of goods, which are currently handled mainly in Moscow and St. Petersburg. By some estimates, $60-80 \%$ of goods coming to Moscow have a transit destination.

Construction of the TLCs is massive and spontaneous; there is a lack of coordination between the participants of the transport market. It promotes the growth of competitive transport and logistics centers built at the initiative of the federal and regional authorities, network and local companies.

During the construction of the TLCs in the regions, there is a problem of return of investments, the emergence of excess warehouse space, the reevaluation of future flows of goods and unfair competition.

The budget efficiency of the implementation of infrastructure (especially, transport and transit) projects at the regional level is not always obvious. Participants of transport and logistics cluster provide benefits to pay state and local taxes and fees, as well as the income tax to the extent payable to the budget of the Russian Federation. This reduces 
the effectiveness of fiscal policy of the cluster in the short term.

The control institutions in the regions, having their forecasts of growth of cargo within the region, as a rule, can not accurately estimate the future growth of transit flows of goods and passengers. In addition, major transport links - these are line features of a large extent, pass through several regions, and connect them with each other. Transportation of cargo and passengers may be carried out by the company from other regions and countries. As a result of infrastructural support of regional development occur in competitive regional and interregional projects for the cargo base, passengers, public and private investments.

The main direction of the competition is the struggle for the allocation of funding from the federal budget, ultimately, for the raw rent. We must take into account the desire of government officials to learn («cut») the cash flow which is directed to the formation of transport and logistics cluster. It is estimated that at least $20 \%$ of the investments are directed to the payment of administrative rent - income from status position, and this proportion tends to increase.

There are problems in the construction of the TLCs in the municipalities. Income tax is paid to the federal budget and regional budgets, which discourages local authorities to place the production in their territory. At the same time, the development of the logistics cluster means increased pressure on the road network, environmental degradation and the crime situation in the municipality plus the protests of local residents. In addition, the establishment of transport links to the major city means an increase in commuting and reduction of the revenue base of local budgets in terms of income tax for individuals under the influence of reduction in economic activity in the municipality.

It is necessary to coordinate road construction plans and the TLCs construction with similar projects in neighboring areas. In addition, there is a risk of fluctuations in transit traffic and change of their ways. To smooth the effects of these oscillations, it should be possible to organize substitute industries in the immediate vicinity of the TLCs.

After creating the Customs Union, the poor quality of Russian customs work promotes the reorientation of traffic at the border of Kazakhstan and Belarus, companies from these states will continue receiving revenues from the provision of warehousing and transportation services. Forming a single economic space in the Customs Union from China to Western Europe requires a network of coordination and logistics centers to improve the competitiveness and profitability of individual transport companies in general. The most important indicators of their activity will increase and decrease transportation costs based on the acceleration of the car traffic, the growth of new rolling stock fleet, reducing the costs of JSC «RZD» and operating companies. The founders of these centers could be the JSC «RZD», Russian Ministry of Transport, ports, large cargo owners and freight forwarding (operators) companies.

Inter-regional competition for freight service on the direction of «East - West» is getting tougher. Let's take as an example the situation in Volga region. In October 2009, in Saratov region the second phase of the bridge across the Volga River near the village of Pristannoe was opened, which is included in the transport corridor «East - West» and provides communications for the center, Volga region and Central Asia. Construction of a bypassing road to the north of Astrakhan will also increase the capacity of the corridor «East - West». At the end of September 2010, in the Republic of Tatarstan, Vysokogorskiy district, a new industrial and logistics park of Class A, Biek Tau, was opened, it is located on the federal highway M7 «Volga». In Ulyanovsk region, a competing project «the Volga transit» was implemented, which is in the construction plan of the route «Middle Volga» and passing through the new bridge across Volga River, it will take $15-20 \%$ of traffic from federal highways M5 «Ural» and M7 «Volga».

Large Russian and foreign shipping companies carry out their own projects, transit and processing of goods. In this connection, it is worth mentioning the work on the implementation of the Concept of development of terminal and warehouse activity of JSC «RZD», terminal projects of companies «Transcontainer», «Eurosib», FESCO group and others.

The implementation of the Concept of development of terminal and warehouse activities of the largest network company — JSC «RZD» — provides the first stage of withdrawal from the territories of Moscow, St. Petersburg and Yekaterinburg of freight yards, modernization, renovation and conversion of existing and construction of new infrastructure. The main project is the first phase of construction of terminal and logistics center near the station Bely Rast of Moscow railway. The second stage 
provides the establishment of a support network of 35-40 transport and logistics centers in major areas of goods movement in international transport corridors. The centers will be established at the Moscow, St. Petersburg, Kaliningrad, Novosibirsk, Nizhny Novgorod, Sverdlovsk, Krasnoyarsk, Vladivostok and Novorossiysk transport nodes.

The development of logistics business of OAO «RZD» provides the establishment of multimodal terminal and logistics centers in the Baltic Sea, the Azov-Black Sea and the coastal regions in Russia, and is intended primarily for the transportation of goods in transit service.

The company «Eurosib» is basing on the development of the terminal network within Russia. Movement of cargo occurs between the terminals at the border, where those foreign trade cargoes are processed between domestic terminals, approaching to the places of consumption of imported goods and export of cargo.

Monopolistic nature of the activity of JSC «RZD» impedes the full realization of transport and transit potential of the country. In container handling areas of the railway monopoly, shipments of its subsidiaries are processed first. From January 1, 2008 , the number of the most important stations on the railway network has been reduced from 51 to 32 according to the principle of separation on regional ones and network ones. The major stations are those that are engaged in the formation of transit trains with a turnover of not less than 10 thousand cars a day. First of all, OAO «RZD» invests in the development of these important marshalling yards.

Ensuring transport security requires government subsidies for the development and maintenance of railway infrastructure. According to the Institute of Economics, Ural Branch of the Russian Academy of Sciences, the capacity of the stations Sverdlovsksorting and Nazyvaevskaya are exhausted by 90-100\%. In the main line of the Trans-Siberian Railway, main sorting stations (Perm, Sverdlovsk andNazyvaevskaya) should be reconstructed and detours of Perm and Sverdlovsk nodes should be constructed.

The state annually allocates OAO «RZD» tens of billions of rubles. The conclusion of a «network contract» will influence the conduction of regional economic policy. The state will determine which goods and to what extent and in what areas should be transported in the long term, with a division yearby-year, what should the speed of traffic and quality of services be. Placement of new production facili- ties will be made on the basis of the conditions of the network contract, and vice versa.

To the provision of economic security during the construction of regional transport and logistics centers contribute the following factors:

- construction of new and reconstruction of existing roads, especially bypasses and detours of major cities;

- availability of rolling stock owned by the regional companies or companies with a share of the property owned by administrations of the Federation: regional car fleet, merchant marine etc.;

- construction of new railway stations and tracks of sludge for regional wagon parks;

- maintainance in a regulatory status and the development of non-public ways in which traffic flows are generated and executed at more than $80 \%$ of all freight operations, increase efficiency and entry into the capital of industrial enterprises of railway transport (quite often, the ways of non-public usage are already owned by the regional and municipal enterprises);

- formation of regional container operators, creation of regional container-handling areas equipped with modern technologies, which can be an alternative to building large TLCs;

- coordination of work on the organization of multimodal transport, docking of various means of communication, creation of management companies with the participation of regional authorities in the ports to coordinate the work of the transport, entry into the capital of the seaports, financing of construction and reconstruction of the port infrastructure.

\section{Organization of border control and customs activity in order to ensure transport safety}

Imperfection of border and customs procedures is a serious obstacle in the path of export-import movement and transit of goods.

A key role in the attractiveness of a regional TLC is in its possiblility of providing customs clearance, regardless of proximity to the state border. Registration of export-import cargoes on inland customs stations led to the formation of centers of business activity in the domestic territory. In the process of transferring the customs procedures to the external borders of Russia, only a small portion of the internal customs offices (at seaports, airports and near major businesses) will retain its current location. The emergence of a situation in which customs clearance can take place only near the border, will lead not only to 
redistribution of ancillary businesses. The same aim is pursued by the practice of changing the terminals, on which the customs clearance of goods is taking place, in the course of the reorganization of customs administrations. For cross-border regions, this situation creates the conditions for accelerated socio-economic development. For example, transit potential of Pskov region will be fully involved, located on the border between Russia and the European Union, in the border areas of the region few customs and logistics centers will be built.

By the beginning of 2011, the number of checkpoints in Moscow region was reduced from 128 to 20. The time required for customs procedures has increased by several times. Border crossing points are often located in small towns and remote areas, which exacerbates the problem of lack of qualified personnel. Not enough qualified are the customs officials in Pskov, Novgorod, Smolensk, Bryansk and other areas.

Since 2004, the customs authorities are working on a system of risk management, which involves random checks of containers. Selected for screening by a computer, containers are to be found, brought, and after inspecting returned to the railway train. The container may be blocked by other containers. As a result, the processing may be delayed for two to three days.

The problem is solved by equipping customs offices with Inspection-Screening Systems (ISS), based on X-ray machines, allowing inspection of consignments of cargoes without unloading cars, wagons and containers. An example of institutional solution to the problem is the situation in Kazakhstan, where the services of veterinary, phyto-sanitary and epidemiological control were transferred to the operational control of the customs.

It is necessary to introduce a single waybill, jointabsorbing marine bill of lading and consignment note. Encumbrance of foreign economic activity is the determination of the customs value of goods. In the customs value of goods in Russia, both the cost of the goods and the cost of transporting those is included. The problem is acute in the activities of air transport, which usage has a significant influence on the final price of the goods. The current taxation leads to the fact that the airlines from China do not fly to Moscow but to Helsinki, Riga or Warsaw, where the goods are loaded onto road transport and delivered to Russia (Moscow).

In order to reduce the time of registration of the vehicle at the border or in the inland areas of countries - participants of the Customs Union, a statutory time limit for customs clearance of goods should be introduced.

\section{Problems and prospects of building transit transport infrastructure facilities (for example, «White Sea - Komi - Urals» (Belkomur) railway construction)}

The competitive nature of the struggle for the transit cargo flows can be illustrated on the railway project «The White Sea - Komi - Urals» (Belkomur), the total length of $1311 \mathrm{~km}$. (new construction should reach over $700 \mathrm{~km}$. of the total length of the line). The road shortens the distance of transportation from the regions of Siberia and the Urals into the ports of Arkhangelsk, Murmansk and the Scandinavian countries $(400-800 \mathrm{~km}$.), reducing the cost of transportation by $40 \%$ (despite the intended use of diesel traction).

Construction of the railway involves the reconstruction of existing routes and new construction of two missing parts: the northern Vending - Karpogory (length of $215 \mathrm{~km}$ ) and the southern Syktyvkar - Gainy — Solikamsk (length of 590 $\mathrm{km})$.

Construction of the highway that would connect ports in the Barents and White seas with industrial enterprises of the Urals and Siberia on the shortest path, was discontinued in the mid-1950s because of the increased cost of labour and the changing priorities of governmental economic policy.

Construction of «Belkomur» is a part of the regional development program of Perm territory, Komi Republic and Arkhangelsk region, as well as Kirov region and the Republic of Karelia. These regions already have access to a network of railways, but in most cases it occurs in the form of infrastructure impasses. The railroad must provide access to the new natural resources (allowable cutover area of the regions is mastered by no more than 15\%), straighten and shorten the current route from the Urals to the White Sea, bypass around the loaded transport nodes, effectively overcome the raw and dead-end nature of the railways in the region (particularly in case of transmission line on the route Solikamsk - Arkhangelsk) and increase their transport and transit potential. The railway will strengthen the transport axis East - West, including the transportation of goods from Central Asia to the Far East.

The areas are assigned to develop a combined business plan to prove the cargo base and a large 
amount of economic benefit from the project. There are several options for building the railway. According to one of those, the line will be laid along the route Perm - Kudymkar - Syktyvkar - Arkhangelsk. According to another one, embodiment of the railway will include $53 \mathrm{~km}$. detour of Berezniki route via Yaiva - Solikamsk. To speed up the construction, it is also expected to use the single-track railway timber cargo through the territory of Kirov region, which is administered by the Ministry of Justice and Chief Directorate for Punishment Implementation of Russia. Construction next to the railroad industry is anticipated, which will accelerate the return on the project. On the territory of Karelia, Belkomur, can be connected to the railway line Ledmozero - Kochkoma which is serving the transportation for JSC «Karelian Pellet» («Karel'skiyokatysh»).

The total volume of future traffic via Belkomur is estimated at 24 million tons per year, it will become the main cargo of steam coal, bauxite ore, coking coal, alumina and potash (about 11 million tons per year). On the basis of Berezniki-Solikamsk industrial cluster, the entire Northern District of Perm region will develop. Private investors should invest in the development of mineral deposits and forest resources along the railway. Transportation of roundwood to Finland will be implemented with minimal cost; the export of coal via shipments from Pechora coal-mining field will be simplified and become profitable. Highway will be the shortest route for the delivery of Timan bauxite to aluminum plants in the Urals and Western Siberia. It is planned to create a base port for the regions of the Volga Federal District on the basis of the Arkhangelsk sea port.

Currently, the Arkhangelsk port is not powerful enough and does not have the desired depth of the fairway. As part of the project implementation, the establishment of a new deepwater port of Arkhangelsk region and laying of $55 \mathrm{~km}$ of the railroad to it is planned.

Belkomur and the new port will open additional exits to the main shipping artery of Russia in the Arctic - the Northern Sea Route. The project is associated with the development of transportation along the Northern Sea Route. Construction of the railway line on the western shore of the Kola Bay should increase the loading port of Murmansk. Murmansk port will lose a significant portion of imported goods.

The problem is the lack of sufficient cargo base and reliable predictions of its increase. In addition, the impact of the railroad on the growth of transit needs additional evidence, which is sometimes replaced with declarations of intent and good wishes. Perspective on Belkomur cargo is estimated at 35.5 million tons annually.

Another problem is the search for reliable information and the cut-off of lobbying efforts to obtain state funding and securing a monopoly position, in particular, OAO «RZD».

Construction of the railway will generate the necessary competitive environment. There will be a competition for attracting cargo between Murmansk, Archangelsk and Baltic ports. Connection of Belkomur with Finland and Norway will alternate terrestrial consignment to the Scandinavian countries and ports. Belkomur will attract cargo from a network of JSC «RZD», which stands for the project only after 2020, when fully loaded line will exist. It is also envisaged that the participation of JSC «RZD» in the project will be consultative and organizational. It may also be real that existing lines undergo reconstruction and modernization.

Development of transit traffic in Belkomur requires its connection with other infrastructure projects and exchange of information with potential consumers of transit services. In the West, such a project is supported by the European Union railway route, «Barents Link», which is part of the Northern Corridor «East - West». The aim of the project is the development of rail transport in Norway, Sweden and Finland into Russia with access to the railway line Belkomur and further to the TransSiberian Railway.

It is necessary to inform the consumers of railways and transport services in the Central Asian countries (mainly in Kazakhstan and Uzbekistan) on the competitive advantages of the new transit route, the possibility to carry out export-import operations through the reconstructed ports of Murmansk and Arkhangelsk. Port of St. Petersburg and Novorossiysk are overloaded and transportation through the Baltic ports requires additional crossing of the border.

The line should be an integral part of the Eurasian transport corridor Barents - Link and the North of the international transport corridor on the Northeast U.S. and Canada (Boston, Halifax) - Northern Europe - Russia - Kazakhstan China and other countries in the Asia-Pacific region. Consignments must be delivered from the Urals to the ports of the White and Barents Seas (Northern East-West (N.E.W.)). 
It is planned to build s monorail way on the diesel locomotive operation. Lack of electrification not only reduces the cost of the project, but also helps to organize train cargo using own transport units.

In general, we may notice that the centralization of the transport process contributes to the further electrification of railways and the development of competition requires increased use of diesel traction as a more flexible (in the choice of route) type of rolling stock (like heavy load trucks).

The objective of LLC «Interregional investment company «North - West - Kama»,» is the economic justification of the project of a comprehensive program of industrial and infrastructural development of the three regions and the preparation of the application to the Investment Fund.

The coordinating role of the government is to agree on the choice of optimal routes and new railway roads. It is necessary to answer the question of ownership of the route: it will become a part of the common ways of JSC «RZD» or will be a private road. For the construction of the railroad, a union, a corporation in which the rights of co-sponsors will include large industrial enterprises and the administration of the regions concerned, is created. Construction of «Belkomur» not only does not contradict, but is an integral part of transport infrastructure development in Siberia and the Far East.

Funds for the preparation of construction documents and implementation of the project (about 100 billion rubles) are expected to be received from the Federal Investment Fund.

The program implementation is estimated at 350 billion rubles. The funds of the investment fund are planed to be used for building of the southern and northern sections of the railway (about 100 billion rubles in 2007 prices) and the access roads to the port of Arkhangelsk (5 billion rubles). Private investors should finance the construction work of the new deep water port of Arkhangelsk region (about 45 billion rubles) and implement their own projects, which form the base of the freight road. To meet the requirements of attracting each ruble invested by the state for at least three rubles of private investment, total investment of companies must be at least 300 billion rubles. This is a big problem even in the post-crisis recovery, in addition, problems involving the investor for the construction of a deep water port in Arkhangelsk. By 2020, the plans are to commission a new deep-water area of the «North» Arkhangelsk sea port in Dry Sea Bay, which is able to accommodate vessels with carrying capacity up to $70-80$ thousand tons.

At various times, up to 15 industrial enterprises were planning to participate in this project. However, the large private companies have no hard plans for sustainable development, which is quite natural in a changing external economic environment, private property and the specific features of Russian government. For example, the amount and structure of cargo «Belkomur» depends on the size of the export duties on raw timber («round logs»). Traffic volumes of deeply processed wood are much less than the raw.

An interested party may be the company «Rusal», which has had problems with the supply of natural gas to a combined heat and power station that provides electricity to the production complex in the Middle-Timan bauxite deposit.

Work on the preparation and mastering of public financing is one of the main incentives for the development of major infrastructure projects. Only the preparation of design estimates for construction of the railway is measured at about 150 million rubles. The development of inter-regional integrated program will cost about 6 billion rubles. These funds will come from the Investment Fund of the Russian Federation on conditions of parity of funding from regional budgets.

Implementation of the plan of railway construction could be delayed for an indefinite period, the project is risky.

Please see journal issue №2 for the second part of this paper.

\section{References}

1. Zoidov K. Kh., Medkov A. A., Tsvetkov V. A. (Ed.) (2011). Transportno-tranzitnyy potentsial Rossii: problem i napravleniya razvitiya. Problemy razvitiya rynochnoy ekonomiki [Transport and transit potential of Russia: problems and directions of development. Problems of market economy development]. Moscow: TsEMI RAN [Central Economics and Mathematics Institute, the Russian Academy of Sciences].

2. Pluzhnikov K. (2007). Ne vernut'sya li k sovetskoy praktike organizatsii perevozok tranzitnykh gruzov? [Should we return to the Soviet practice of organizing transport of goods in transit?]. Mezhdunarodnyy ekspeditor [International Expeditor], 2. Available at: http://old.morvesti.ru/slog/exp-arj/2007/2/8.asp (Accessed 07 September 2010).

3. Stimulirovanie eksporta rossiyskikh transportnykh uslug trebuet sozdaniya krupnogo igroka konteynernogo rynka [Stimulation of the export of Russian transport services requires the creation of a major player in the container market]. Transport 
Rossii [Transport of Russia], 46 (11 November 2010). Available at: http://www.transportrussia.ru/logistika/tehnologii-buduschego. html (Accessed 23 May 2011).

4. Tsvetkov V. A., Zoidov K. Kh., Medkov A. A. (2010). Problemy integratsii i innovatsionnogo razvitiya transportnykh system Rossii i stran Tsentral'noy Azii [The problems of integration and innovative development of transportation systems in Russia and Central Asia]. Moscow: TsEMI RAN [Central Economics and Mathematics Institute, the Russian Academy of Sciences].

5. Tsvetkov V. A., Medkov A. A. (2008). Perspektivy gosudarstvenno-chastnogo partnerstva pri stroitel'stve i rekonstruktsii zheleznodorozhnoy infrastruktury [Prospects for public-private partnership in the construction and reconstruction of railway infrastructure]. Zhurnal ekonomicheskoy teorii [Journal of Economic Theory], 1, 170-182.

\section{Information about the authors}

Tsvetkov Valeriy Anatol'evich (Moscow) - Corresponding Member of the RAS, Doctor of Economics, Professor, Deputy Director for Science, Institute of Market Problems, the Russian Academy of Sciences (117418, Moscow, Nakhimovskiy prospekt, 47, e-mail: tsvetkov@cemi.rssi.ru).

Zoidov Kobilzhon Khodzhievich (Moscow) - Ph.D. in Physics and Mathematics, Associate Professor, head of the laboratory, Institute of Market Problems, the Russian Academy of Sciences (117418, Moscow, Nakhimovskiy prospekt, 47, e-mail: kobiljonz@ mail.ru).

Medkov Aleksey Anatol'evich (Moscow) - Ph.D. in Economics, senior research scientist, Institute of Market Problems, the Russian Academy of Sciences (117418, Moscow, Nakhimovskiy prospekt, 47, e-mail: medkov71@mail.ru). 